\title{
Katalog prírodě blízkých opatření pro zadržení vody v krajině a jeho uplatnění ve webové mapové aplikaci pro veřejnost
}

\section{MIRIAM DZURÁKOVÁ, PAVLA ŠTĚPÁNKOVÁ, VIKTOR LEVITUS}

\author{
Klíčová slova: katalog opatření - sucho - retence vody - přírodě blízká opatření - opatření v ploše povodí - \\ malé vodní nádrže - opatření na tocích - webová mapová aplikace
}

\section{SOUHRN}

Katalog prírodě blízkých opatření pro zadržení vody $\vee$ krajině je jedním z výstupů řešení problematiky sucha $v$ gesci Ministerstva životního prostředí. Hlavním cílem bylo sestavit soubor opatření, která jsou vhodná pro zvýšení retence vody v krajině a zároveň nemají významný negativní vliv na ekologický stav vodních útvarů. Tento katalog představuje metodickou pomůcku pro návrhy systémů opatření při adaptaci území na projevy extrémních hydrologických situací - především sucha a povodní. Jednotlivé katalogové listy popisují možné způsoby realizace a využití opatření v území včetně krátkého shrnutí jejich prípadných vlivů na složky životního prostředí a společnost. Katalog by měl napomoci k jednotnému přístupu při prípravě, návrhu a realizaci účinných systémů opatření v rámci hydrologických celků. Pro podporu realizace opatření v ploše povodí a na vodních tocích a za účelem posílení osvěty veřejnosti byla $v$ souladu s katalogem opatření připravena interaktivní webová mapová aplikace Typová opatření pro zadržení vody v krajině, kde jsou na vzorových lokalitách navrženy komplexní soubory opatření s popisem jejich očekávaných účinků.

\section{ÚVOD}

Sucho je jedním z projevů globální změny klimatu. Jedná se o dočasný přirozený jev, který může vést k nedostatku vody, kdy požadavky na užívání vodních zdrojů presahují jejich přirozenou dlouhodobou obnovitelnost. Měnící se přírodní podmínky spolu se změnami socioekonomických poměrů vedou k rostoucímu tlaku na potřebu vodních zdrojů, a ty v mnoha prípadech již nedostačují potřebám. Řada států proto prijijala strategické dokumenty definující soubor adaptačních a mitigačních opatření vưči projevům klimatických změn, včetně nedostatku vody.

Na území České republiky se do budoucna očekává víceméně stejný roční úhrn srážek v porovnání s minulými obdobími, mění se však jejich charakter a distribuce $v$ čase i prostoru. Lze očekávat mnohem vyšší četnost hydrologických extrémů - prívalových srážek a povodní a zejména období sucha [1].

Vláda České republiky iniciovala v roce 2015 svým usnesením prípravu realizace opatření pro zmírnění negativních dopadů sucha a nedostatku vody, která následně vyústila ke schválení strategického dokumentu Koncepce ochrany před následky sucha pro území České republiky [2] (dále jen Koncepce) dne 24. července 2017.
Součástí Koncepce, jako jedna z jejích přiloh, je uveden seznam plošných a liniových opatření na zemědělské a lesní půdě a opatření na tocích a v údolních nivách, která jsou obecně vhodná pro zvýšení retence vody v krajině a zároveň zlepšují (nebo alespoň nezhoršují) ekologický stav vodních útvarů. $\checkmark$ návaznosti na tento seznam byl zpracován podrobný Katalog přírodě blízkých opatření pro zadržení vody v krajině s detailním popisem vybraných parametrů, charakteristik a účinků typových opatření.

\section{KATALOG PŘíRODĚ BLÍZKÝCH OPATŘENÍ PRO ZADRŽENÍ VODY V KRAJINĚ}

Práce na sestavení Katalogu prírodě blízkých opatření pro zadržení vody v krajině (dále jen Katalog) navázaly na výstupy projektů a úkolů řešených pracovníky Výzkumného ústavu vodohospodářského T. G. Masaryka, v. v. i. (dále jen VúV TGM). Mezi ně patři především projekt Strategie ochrany před negativními dopady povodní a erozními jevy prírodě blízkými opatřeními v České republice [3], jehož výsledky jsou publikovány na portálu www.vodavkrajine.cz. Cílem projektu byly návrhy komplexních systémů protipovodňových a protierozních opatření v ploše povodí na zemědělské i lesní pưdě a opatření na vodních tocích a v nivách. Při sestavování Katalogu bylo rovněž využito poznatků získaných z řešení projektu Nové postupy optimalizace systémů integrované ochrany území v kontextu jejich ekonomické udržitelnosti [4].

Katalog vychází také z dílčích výstupư úkolů řešených pro MŽP v rámci podpory výkonu státní správy v problematice sucho v letech 2016-2018 [5, 6]. V průběhu těchto let byl vypracován seznam opatření na zemědělské a lesní půdě a na tocích a údolních nivách, která jsou obecně vhodná pro zvýšení retence vody $v$ krajině. Při jejich výběru byl kladen dưraz na to, aby tato opatření minimálně nezhoršovala ekologický stav vodních útvarů.

Katalog vymezuje pět druhů opatření, která se dále dělí na 26 typů opatření (tabulka 1). Některé typy opatření jsou dále členěny na detailní typy (např. průlehy, př́kopy) nebo komponenty (např. revitalizace). Rovněž typ opatření malé vodní nádrže (dále MVN) je rozdělen na detailní typy podle ČSN Malé vodní nádrže [7]. Zařazeny byly ty, které se ukázaly jako vhodné pro zadržení vody $\checkmark$ krajině. Pro komplexní pohled na retenci vody byl Katalog doplněn o dva další druhy opatření, a to agrolesnická opatření a hospodaření s deštovou vodou. 


\begin{tabular}{|c|c|c|}
\hline Druh opatření & Typ opatření & Detailní typ opatření \\
\hline \multirow{12}{*}{$\begin{array}{l}\text { PLOŠNÁ OPATŘENÍ } \\
\text { NA ZEMĚDĚLSKÉ } \\
\text { PŮDĔ }\end{array}$} & \multirow{4}{*}{ organizační } & $\begin{array}{l}\text { návrh vhodného tvaru } \\
\text { a velikosti pozemku }\end{array}$ \\
\hline & & trvalé zatravnění a zalesnění \\
\hline & & $\begin{array}{l}\text { protierozní osevní postupy } \\
\text { a protierozní rozmistování } \\
\text { plodin }\end{array}$ \\
\hline & & pásové střídání plodin \\
\hline & \multirow{4}{*}{ agrotechnická } & $\begin{array}{l}\text { technologie ochranného } \\
\text { zpracování půdy }\end{array}$ \\
\hline & & hrázkování/důlkování \\
\hline & & mulčování \\
\hline & & setí do krycí plodiny \\
\hline & \multirow{4}{*}{$\begin{array}{l}\text { opatření na } \\
\text { speciálních } \\
\text { kulturách }\end{array}$} & zatravnění meziřadí \\
\hline & & hrázkování/důlkování meziřadí \\
\hline & & mulčování \\
\hline & & vrstevnicový směr výsadby \\
\hline \multirow{14}{*}{$\begin{array}{l}\text { BIOTECHNICKÁ } \\
\text { OPATŘENÍ }\end{array}$} & \multirow{3}{*}{ průleh } & záchytný \\
\hline & & svodný \\
\hline & & zasakovací (retenční) \\
\hline & \multirow{3}{*}{ príkop } & záchytný \\
\hline & & svodný \\
\hline & & zasakovací (retenční) \\
\hline & \multicolumn{2}{|l|}{ zasakovací pás } \\
\hline & \multicolumn{2}{|l|}{$\begin{array}{l}\text { stabilizace dráhy } \\
\text { soustředěného } \\
\text { odtoku }\end{array}$} \\
\hline & \multirow{2}{*}{ hrázky } & záchytné \\
\hline & & zasakovací (retenční) \\
\hline & \multicolumn{2}{|l|}{ meze } \\
\hline & \multicolumn{2}{|l|}{ přehrážky } \\
\hline & \multicolumn{2}{|l|}{ terasy } \\
\hline & \multicolumn{2}{|l|}{ větrolamy } \\
\hline
\end{tabular}

\begin{tabular}{|c|c|c|}
\hline Druh opatření & Typ opatření & Detailní typ opatření \\
\hline \multirow{6}{*}{$\begin{array}{l}\text { MALÉ VODNÍ } \\
\text { NÁDRŽEE }\end{array}$} & \multirow{6}{*}{ malé vodní nádrže } & vodárenské \\
\hline & & závlahové \\
\hline & & retenční suché \\
\hline & & $\begin{array}{l}\text { retenční nádrže s malým } \\
\text { zásobním prostorem }\end{array}$ \\
\hline & & Čisticí a usazovací \\
\hline & & $\begin{array}{l}\text { krajinotvorné nádrže ležící } \\
\text { mimo vodní tok }\end{array}$ \\
\hline
\end{tabular}

\begin{tabular}{|c|c|}
\hline \multirow{9}{*}{ OPATŘENÍ V LESÍCH } & $\begin{array}{l}\text { tvorba polyfunkčního lesa s pestrou dřevinnou } \\
\text { skladbou }\end{array}$ \\
\hline & omezení smrku ve 3. a 4. LVS \\
\hline & $\begin{array}{l}\text { podpora hospodářských způsobů s trvalým } \\
\text { pưdním krytem s dlouhou nebo nepřetržitou } \\
\text { obnovní dobou }\end{array}$ \\
\hline & $\begin{array}{l}\text { vhodné postupy při těžbě a důsledná sanace } \\
\text { potěžebních či jiných technologických narušení } \\
\text { půdy }\end{array}$ \\
\hline & nízký les \\
\hline & $\begin{array}{l}\text { ochranné lesní pásy kolem vodohospodářsky } \\
\text { významných vodních toků }\end{array}$ \\
\hline & hrazení strží \\
\hline & hrazení bystřin \\
\hline & ochrana lesních pramenů a prameništ’ \\
\hline \multirow{4}{*}{$\begin{array}{l}\text { OPATŘENÍ NA } \\
\text { TOCÍCH A V NIVÁCH }\end{array}$} & opatření na tocích v nezastavěných územích \\
\hline & opatření na tocích v zastavěných územích \\
\hline & opatření v údolních nivách toků \\
\hline & mokřadní biotopy \\
\hline
\end{tabular}


Tabulka 2. Struktura katalogového listu

Table 2. Structure of the catalog sheet

\section{Katalogový list opatření}

\begin{tabular}{|c|c|c|c|}
\hline ID opatření & & & \\
\hline Druh opatření & & & \\
\hline Popis & & & \\
\hline Technické parametry & & & \\
\hline Podmínky realizace & & & \\
\hline Možné střety & & & \\
\hline Interakce/synergie & & & \\
\hline Stanovení nákladů & & & \\
\hline & & krátkodobá & $0-3$ let \\
\hline & $\begin{array}{l}\text { Příprava } \\
\text { a realizace }\end{array}$ & střednědobá & 4-6 let \\
\hline & & dlouhodobá & 7 a více let \\
\hline & & krátkodobá & $0-3$ let \\
\hline & Rychlost efektu & střednědobá & 4-6 let \\
\hline & & dlouhodobá & 7 a více let \\
\hline
\end{tabular}

\section{Řez/situace}

Pokud je k dispozici

\section{Fotodokumentace př́kladů realizací}

Pokud je k dispozici

\section{Hodnocení vlivu opatření}

Detailní typ

Charakteristika

A) Vliv na kvantitu vody

B) Vliv na hydromorfologii toku

C) Vliv na kvalitu vody

D) Vliv na vodní a vodu vázané ekosystémy

E) Vliv opatření na krajinu a suchozemské ekosystémy

F) Socioekonomický dopad

N) Ekonomické náklady na realizaci a údržbu

Všechny typy opatření jsou popsány formou jednotného katalogového listu (tabulka 2), který obsahuje základní charakteristiky opatření, popis jejich interakce a vlivu na složky životního prostředí i společnost, schematické nákresy opatření, fotodokumentaci príkladů jejich realizací a rovněž časové hledisko př́ipravy a realizace a rychlosti dosažení očekávaného efektu jednotlivých opatření. Osnova katalogového listu je částečně inspirována i strukturou katalogu opatření pro plánování [8] podle směrnice 2000/60/ES.
Tabulka 3. Kritéria hodnoceni účinnosti opatřeni

Table 3. Criteria for evaluating the effectiveness of the measure

\section{A. Vliv na kvantitu vody}

1 - snížení objemu odtoku

2 - snížení rychlosti odtoku

3 - zvýšení vsaku do půdního profilu a podzemních vod

4 - vytvoření zásoby vody pro využití v období sucha

5 - nadlepšování průtoků v období sucha

\section{B. Vliv na hydromorfologii toku}

1 - podpora príirozené struktury dnových sedimentů

2 - habitatová diverzita (refugia pro vodní organismy)

3 - zvýšení migrační prostupnosti

4 - podpora přirozeného vývoje vodního toku

\section{Vliv na kvalitu vody}

1 - podpora samočisticích procesů

2 - omezení eutrofizace povrchových vod

3 - omezení vnosu znečištění cizorodými látkami

4 - snížení odnosu půdy do povrchových vod

\section{Vliv na vodní a vodu vázané organismy}

1 - vliv na ryby

2 - vliv na makrozoobentos

3 - vliv na fytobentos

4 - vliv na cévnaté rostliny

5 - vliv na obojživelníky

\section{E. Vliv na krajinu a suchozemské ekosystémy}

1 - snižení erozní činnosti

2 - tvorba nových biotopů

3 - podpora biodiverzity

4 - rozčlenění obhospodařovaných ploch do menších celků

5 - zlepšení migrační prostupnosti

\section{F. Socioekonomický dopad}

1 - podpora rekreace a turistiky

2 - zvýšení estetické hodnoty krajiny

3 - snižení degradace půdy

4 - zvýšení pracovních príležitostí pro místní obyvatele

5 - podpora živočišné výroby

6 - změna mikroklimatu

Celkem bylo vytvořeno 13 katalogových listů pro opatření na zemědělské půdě a samostatný list pro MVN. Opatření na lesní půdě jsou uvedena na celkem devíti katalogových listech a pro opatření na tocích a v nivách existují čtyři katalogové listy. Agrolesnická opatření a hospodaření s deštovou vodou jsou stručně charakterizovány každé na jednom listě.

Součástí prací na sestavení Katalogu bylo také hodnocení opatření z hlediska jejich účinnosti a efektivnosti na zvýšení retence vody $v$ krajině. Výběr hodnoticích kritérií byl koncipován tak, aby zohlednil i možné dopady opatření na ekologický stav vodních útvarů. Celkem bylo definováno šest skupin těchto kritérií, pro které bylo stanoveno od 4 do 6 hodnoticích hledisek (tabulka 3). 


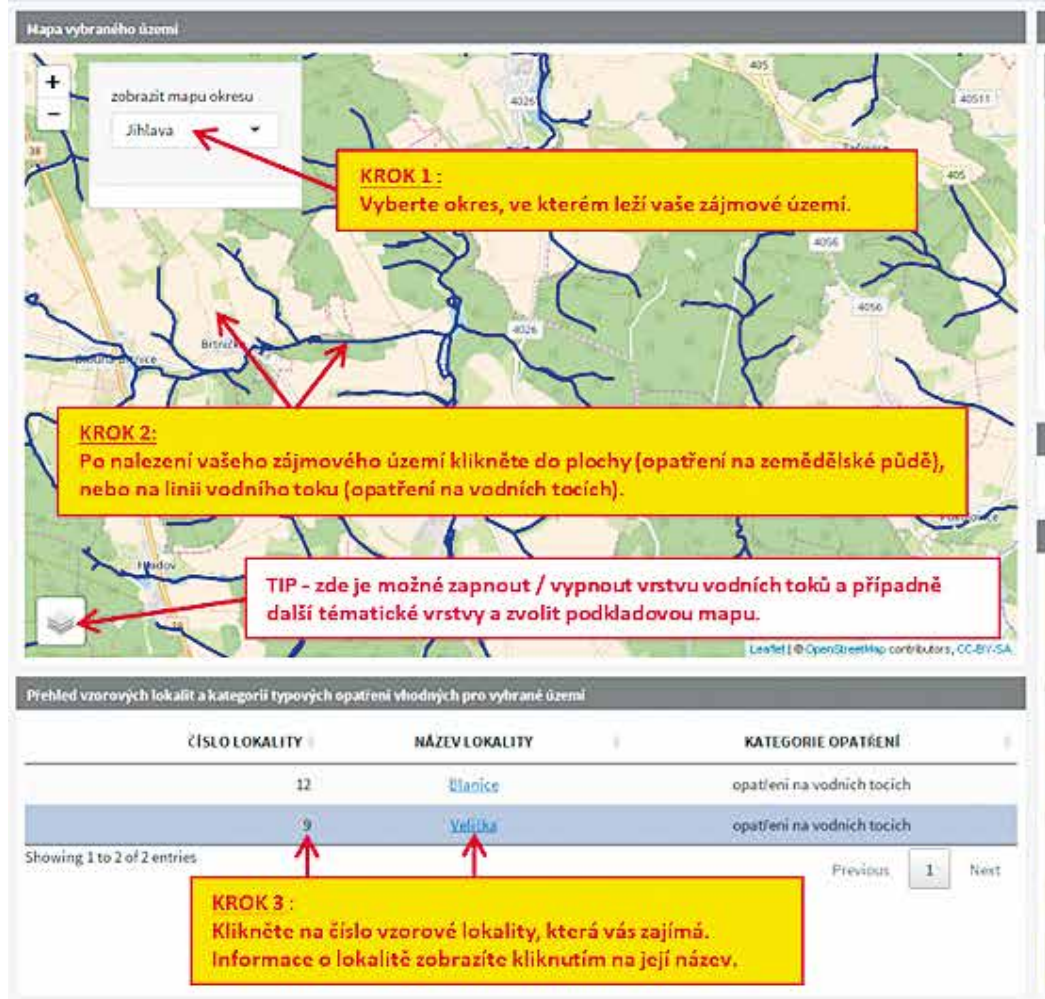

Obr. 1. Webová mapová aplikace Typová opatření pro zadržení vody v krajině

Fig. 1. Web map application Typical measures for water retention in the landscape

Slovní popis hodnocení je součástí každého katalogového listu a odráž výsledky semikvantitativního hodnocení efektivity opatření, které bylo realizováno metodou multikriteriální analýzy. Toto hodnocení je podrobně popsáno v závěrečné zprávě VúV TGM, viz [6], a výsledky ve formě nástroje hodnocení efektivnosti opatření jsou součástí metodického návodu [9], který je volně dostupný na portálu www.suchovkrajine.cz.

Katalog je dostupný na informačním webovém portálu Sucho $v$ krajině (http://suchovkrajine.cz) v části Výstupy.

\section{APLIKACE TYPOVÁ OPATŘENÍ PRO ZADRŽENÍ VODY V KRAJINĚ}

Souběžně s Katalogem byla připravena webová mapová aplikace Typová opatření pro zadržení vody v krajině (dále jen Mapová aplikace), která je postavena na technologiích programovacího jazyka R [10] a nástrojů HTML5 [11]. Jako podklad využívá Mapová aplikace mapy ve formátu OpenStreetMap (polohopisná mapa) [12] a ortofotomapu ČÚZK.

Mapová aplikace je koncipována jako nástroj pro podporu realizace opatření v ploše povodí a na vodních tocích a za účelem posílení informovanosti široké veřejnosti. Základem Mapové aplikace je soubor tzv. vzorových lokalit s realizovanými nebo navrženými komplexy opatření. Celkem bylo vybráno 17 vzorových lokalit pro opatření na zemědělské půdě a 11 vzorových lokalit pro toky a nivy mimo zastavěné území. Cílem bylo zvolit co nejrůznorodější lokality podle charakteru území a zároveň postihnout co nejširší škálu typů opatření.

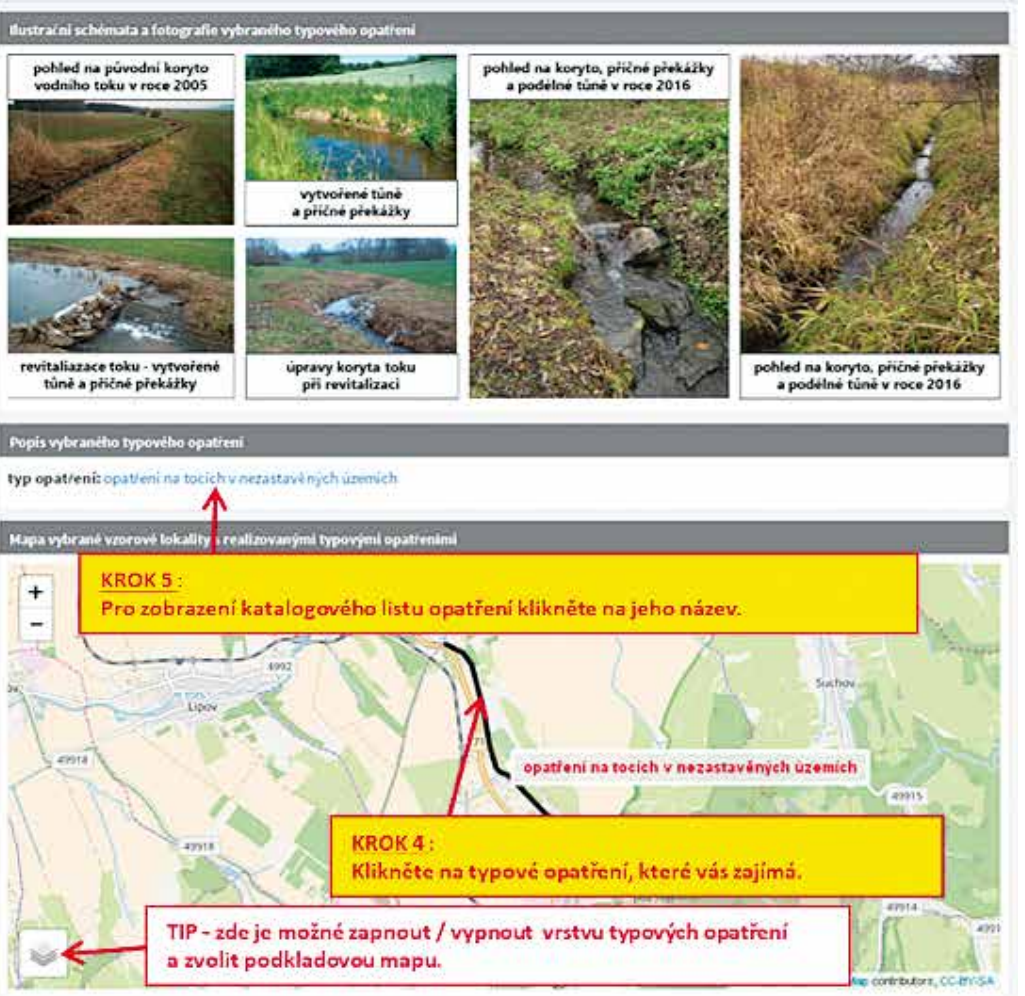

Pro každou vzorovou lokalitu opatření na zemědělské půdě byly na základě klastrové analýzy sestaveny soubory základních fyzicko-geografických charakteristik vztažených $k$ povodím 4. rádu. Kombinace hodnot těchto charakteristik pak umožňují přiřadit jednu nebo více vzorových lokalit k jednotlivým povodím 4. řádu s podobnými charakteristikami jako možné řešení opatření na zemědělské půdě.

Vzorové lokality na tocích a $v$ nivách jsou kategorizovány podle př́ílušnosti toku do řádu podle Strahlera v kombinaci s nadmořskou výškou. Vhodné úpravy toků v intravilánu jsou popsány pomocí jednoho informačního listu, který uvádí více príkladů. Vzorové lokality opatření na lesní půdě budou doplněny v další fázi tvorby Mapové aplikace.

Uživatel aplikace může všechny př́klady využít pro návrhy systému opatření, a to $v$ libovolné řešené lokalitě $v$ ČR s prihlédnutím na charakteristiky a potřeby daného zájmového území. Mapová aplikace nabídne uživateli seznam vzorových lokalit s komplexy opatření, které jsou pro dané území jako vzor nejvhodnější (obr. 1), a to na základě kategorizace popsané výše. Ke každé vzorové lokalitě je možné v aplikaci otevř́t tzv. informační list lokality, který obsahuje podrobnější popis lokality, realizovaných nebo navržených opatření v ní, včetně popisu jejich účinků z pohledu zlepšení zadržení vody v krajině a výsledků modelování vlivu opatření na objem zadržené vody i na její kvalitu. Zároveň se v jednom z oken aplikace zobrazí situační nákres umístění opatření v prostoru, v dalším fotodokumentace, popř. schéma vztahující se k danému typu opatření a rovněž link na př́ślušný katalogový list.

Webová mapová aplikace je dostupná na webovém portále Sucho v krajině (http://suchovkrajine.cz) v části Mapové kompozice. 


\section{ZÁVĚR}

Katalog prírodě blízkých opatření pro zadržení vody v krajině a mapová aplikace Typová opatření pro zadržení vody v krajině byly vytvořeny s cílem přiblízit problematiku zvýšení retence vody $v$ krajině široké veřejnosti. Katalog je určen jako metodická pomůcka predevším pro projektanty pozemkových úprav a územně plánovacích dokumentací, zpracovatele studií proveditelnosti, orgány státní správy a samosprávy, a to s cílem napomoci jednotnému přístupu při prípravě, návrhu a realizaci komplexních systémů opatření v rámci hydrologického celku. Měl by se stát nedílnou součástí plánovacích procesů, at již podle směrnice 2000/60/ES nebo směrnice 2007/60/ES, kde by měl doplnit již stávající katalogy opatření.

Zejména pro širokou veřejnost je určena webová aplikace Typová opatření pro zadržení vody v krajině, v rámci které uživatelé získají představu, jakým způsobem je ve vybraném území možné řešit zadržování vody v krajině, a to prostřednictvím vybraných príkladů vhodných opatření (nebo systémů opatření) na vzorových lokalitách. V současnosti je aplikace připravena pro řešení opatření na zemědělské půdě a na tocích a v nivách.

Postup, jak Katalog i Mapovou aplikaci využít při návrzích opatření, představuje metodický návod na výběr vhodných opatření pro zadržení vody v krajině [9]. Tento metodický návod by měl napomoci $k$ jednotnému prístupu při prípravě, návrhu a zpracování účinných systémů opatření v rámci hydrologického celku.

Oba představované nástroje jsou součástí webového portálu „Sucho v krajině", který slouží jako informační platforma o jednotlivých krocích směřujících k naplňování úkolů definovaných v Koncepci ochrany před následky sucha pro území České republiky schváleným vládou ČR v červenci 2017.

Opatření zařazená do Katalogu a představená v Mapové aplikaci ve formátu vzorových lokalit tvoři základ pro návrhy komplexních systémů opatření při adaptaci území na projevy extrémních hydrologických situací - nedostatku vody i povodní. Tyto dva extrémy nelze od sebe oddělovat. Obecně mají všechna vhodně navržená opatření stejné cíle - podpoření vsaku vody do půdy, zpomalení povrchového odtoku, prodloužení doby zadržení vody v krajině, bez ohledu na to, zda jsou opatření navrhována jako ochrana před negativními dopady sucha či povodní. Vhodně navržená ochranná opatření v krajině, která jsou Katalogem doporučována, by také měla podporovat ochranu krajinných systémů i obnovu v místech předchozího narušení způsobeného převážně za přispění lidské činnosti.

\section{Poděkování}

Príspěvek popisuje výstupy úkolu Podpora výkonu státní správy v problematice sucho rešeného pro Ministerstvo životního prostředív letech 2016-2018.

\section{Literatura}

[1] HANEL, M., KAŠPÁREK, L., MRKVIČKOVÁ, M. a kol. Odhad dopadů klimatické změny na hydrologickou bilanci v ČR a možná adaptační opatření. Praha: VúV TGM, v. v. i., 2011, 108 s. ISBN 978-80-87402-22-1.

[2] Koncepce ochrany préd následky sucha pro území České republiky [on-line]. Dostupné z: http://eagri.cz/ public/web/mze/ministerstvo-zemedelstvi/koncepce-a-strategie/koncepce-na-ochranu-prednasledky-sucha.html

[3] Strategie ochrany před negativními dopady povodní a erozními jevy př́rodě blízkými opatřeními v České republice. (Ministerstvo životního prostředí, financováno z Operačního programu Životní prostředí, řš̌eno 2014-2015) [on-line]. Dostupné z: http://www.vodavkrajine.cz/

[4] Nové postupy optimalizace systémů integrované ochrany území v kontextu jejich ekonomické udržitelnosti (Ministerstvo zemědělství, projekt QJ1520268, řešeno 2015-2018).

[5] DZURÁKOVÁ, M. a kol. Potenciál aplikace prírodě blizkých opatření pro zadržení vody v krajině a zlepšení ekologického stavu vodních útvarŭ. Činnosti k podpoře výkonu státni správy v problematice SUCHO v roce 2016 - úkol 3702. Závěrečná zpráva. Brno: VúV TGM, v. v. i., 2016, 224 s.

[6] DZURÁKOVÁ, M. a kol. Vyhodnoceni prírodě blízkých opatřeni, katalog opatření. Činnosti k podpoře výkonu státni správy v problematice SUCHO v roce 2017 - úkol 3702. Závěrečná zpráva. Brno: VúV TGM, v. v. i.., 2018,35 s.
[7] ČSN 75 2410. Malé vodní nádrže, Praha, 2011

[8] Katalog opatření. MZe, MŽP, 2005

[9] KOLEKTIV AUTORŮ. Metodický návod na výběr vhodných opatřeni pro zadrženi vody $v$ krajině. Činnosti k podpoře výkonu státni správy v problematice SUCHO v roce 2017. Brno: VúV TGM, v. v. i., 2018, 11 s.

[10] The R Project for Statistical Computing [online]. Dostupné z: https://www.r-project.org

[11] HTML5 Finalized [online]. OSNews. Dostupné z: http://www.osnews.com/story/28003/HTML_5_Finalized [12] OpenStreetMap [online]. Dostupné z: http://www.openstreetmap.cz/

\section{Autoři}

Ing. Miriam Dzuráková

凶miriam.dzurakova@vuv.cz

Mgr. Pavla Štěpánková, Ph.D.

凶pavla.stepankova@vuv.cz

Ing. Viktor Levitus

凶viktor.levitus@vuv.cz

Výzkumný ústav vodohospodářský T. G. Masaryka, v. v. i.

Přispěvek prošel lektorským řizením.

\section{CATALOGUE OF GREEN WATER RETENTION MEASURES IN THE LANDSCAPE AND ITS APPLICATION IN THE WEB MAP APPLICATION}

\section{DZURAKOVA, M.; STEPANKOVA, P.; LEVITUS, V.}

TGM Water Research Institute, p. r. i.

Keywords: catalogue of measures - drought - water retention green measures - measures in the catchment area small water reservoirs - measures on watercourses web mapping application

A catalogue of green water retention measures in landscape represents one of the results of long term project financed by the Ministry of Environment. The main goal of the catalogue was to summarize a set of measures with positive effects on water retention of landscape, with low impact on ecological status of water bodies. This catalogue represents a methodical tool which can be used for proposals of system of measures for adaptation to extreme hydrological events - drought and floods. The catalogue consists of catalogue sheets describing a possible realization and application of measures in the landscape. Each catalogue sheet includes a short summary of a measure's possible impacts on the environment and society. The catalogue should help to unify the approaches to preparation, proposal and realization of effective systems of measures within hydrological units. Examples of good practise of green water retention measures are introduced in web map application where sample localities with proposed or implemented complexes of measures, including descriptions of expected impacts, are shown. 